This work is licensed under a Creative Commons Attribution-NonCommercial 4.0 International License (CC BY-NC 4.0).

\title{
Erratum - Presence and identification of Legionella and Aeromonas spp. in the Great Masurian Lakes system in the context of eutrophication
}

\author{
Karolina Grabowska, ${ }^{1 *}$ Aleksandra Bukowska, ${ }_{1}^{1}$ Tomasz Kaliński, ${ }^{1}$ Bartosz Kiersztyn, ${ }^{1}$ Waldemar Siuda, ${ }^{1}$ \\ Ryszard J. Chróst ${ }^{1,2}$
}

${ }^{1}$ Department of Microbial Ecology and Environmental Biotechnology, Faculty of Biology, University of Warsaw; ${ }^{2}$ Laboratory of Protection and Reclamations of Natural Waters, Biological and Chemical Research Centre, University of Warsaw, Żwirki i Wigury 101, 02-089 Warszawa, Poland

*Corresponding author: karolina.grabowska@biol.uw.edu.pl

Received: 27 May 2020. Accepted: 28 May 2020.

This corrects the article entitled "Presence and identification of Legionella and Aeromonas spp. in the Great Masurian Lakes system in the context of eutrophication" by the authors Karolina Grabowska, Aleksandra Bukowska, Tomasz Kaliński, Bartosz Kiersztyn, Waldemar Siuda, and Ryszard J. Chróst, published with DOI 10.4081/jlimnol.2019.1924. In the Figures 3 and 4 the correct values for the number of studied bacteria are presented.
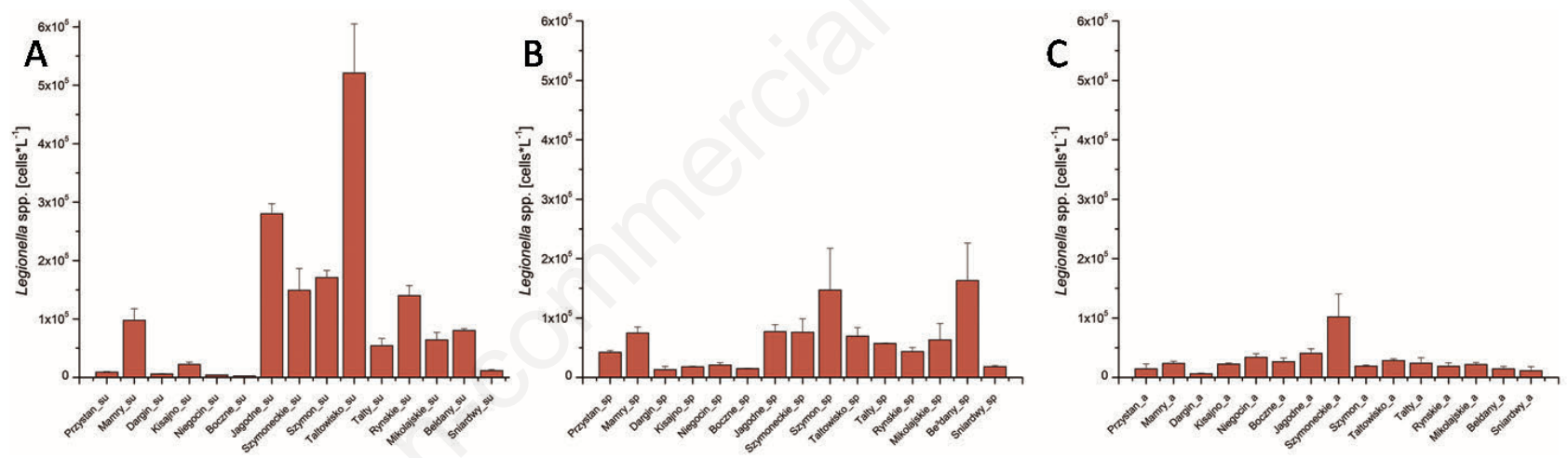

Fig. 3. Legionella spp. cells concentration in studied lakes during summer (a), spring (b) and autumn (c) seasons. Suffixes added to sampling locations (lake's names) indicate the studied seasons:_su - summer, _sp - spring, _a - autumn respectively.
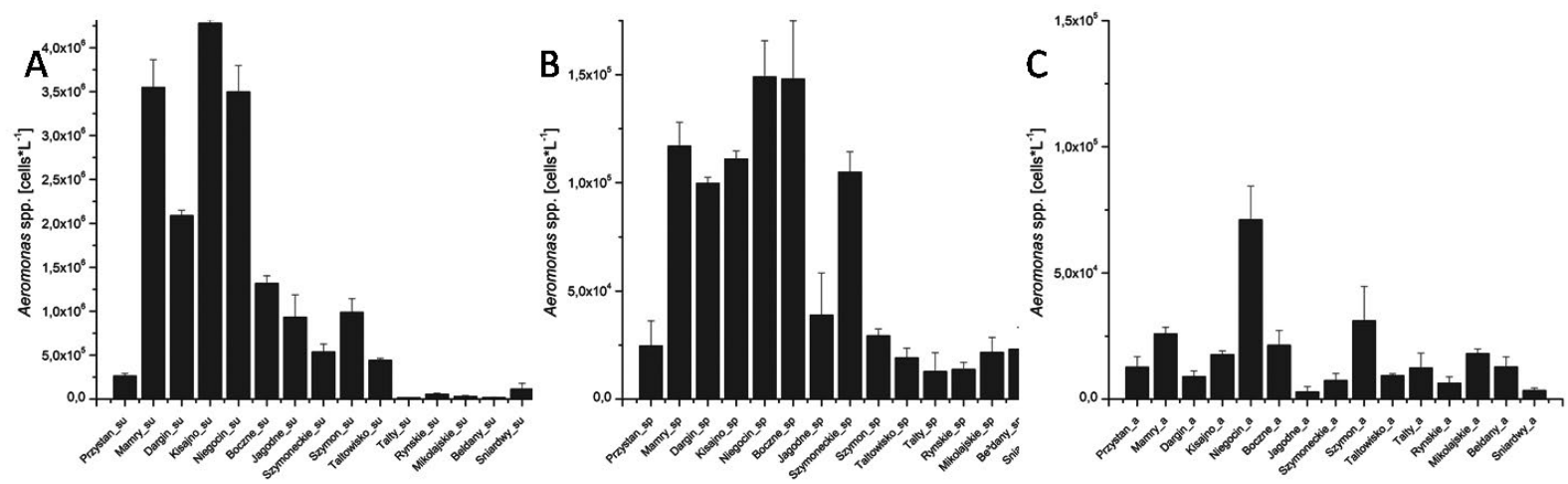

Fig. 4. Aeromonas spp. cells concentration in studied lakes during summer (a), spring (b) and autumn (c) seasons. Suffixes added to sampling locations (lake's names) indicate the studied seasons:_su - summer, _sp - spring, _a - autumn respectively. 